\title{
Enterovirus A71: virulence, antigenicity, and genetic evolution over the years
}

Sheng-Wen Huang ${ }^{1}$, Dayna Cheng $^{2}$ and Jen-Ren Wang ${ }^{2,3,4,5^{*}}$ (D)

\begin{abstract}
As a neurotropic virus, enterovirus A71 (EV-A71) emerge and remerge in the Asia-Pacific region since the 1990s, and has continuously been a threat to global public health, especially in children. Annually, EV-A71 results in hand-footand-mouth disease (HFMD) and occasionally causes severe neurological disease. Here we reviewed the global epidemiology and genotypic evolution of EV-A71 since 1997. The natural selection, mutation and recombination events observed in the genetic evolution were described. In addition, we have updated the antigenicity and virulence determinants that are known to date. Understanding EV-A71 epidemiology, genetic evolution, antigenicity, and virulence determinants can expand our insights of EV-A71 pathogenesis, which may benefit us in the future.
\end{abstract}

Keywords: Enterovirus A71, Epidemiology, Evolution, Recombination, Virulence, Antigenicity

\section{Introduction}

Enterovirus A71 (EV-A71) has caused various symptoms and diseases ranging from hand-foot-and-mouth disease (HFMD), herpangina, rashes, and diarrhea, to aseptic meningitis, pulmonary edema, acute flaccid paralysis (AFP), brainstem encephalitis and Guillain-Barré syndrome [1, 2]. Although EV-A71 infections are often asymptomatic, severe symptoms can also result in neurological disease and even death [2]. Following the first EV-A71 identified in 1969, EV-A71 has been circulating in the Asia-Pacific region such as Japan in the 1970s [3], Asia in the 1980s [4], and Malaysia and Taiwan in the 1990s [1, 5-8]. Since the 1990s, large-scale epidemics have been observed [9]. Since then, EV-A71 infections have caused mortality rates ranging from $<0.5-19 \%$ in Asia-Pacific countries [1, 10-14].

As a member of the genus Enterovirus and the family Picornaviridae, enterovirus A71 (EV-A71) is a nonenveloped positive single strand RNA virus, containing 7.4-kb long RNA with a large open reading frame (ORF) flanked by the $5^{\prime}$ and $3^{\prime}$ untranslated region (UTR) [15]. The 5' UTR consists of stem-loop RNA structures I to VI, which forms the internal ribosome binding site

\footnotetext{
* Correspondence: jrwang@mail.ncku.edu.tw

${ }^{2}$ National Institute of Infectious Diseases and Vaccinology, National Health

Research Institutes, Tainan, Taiwan

${ }^{3}$ Department of Medical Laboratory Science and Biotechnology, College of

Medicine, National Cheng Kung University, Tainan, Taiwan

Full list of author information is available at the end of the article
}

(IRES). Through the use of cap-independent translation mechanism, 5' UTR is involved in viral protein translation and RNA replication [16, 17]. The large ORF is translated into a single polyprotein that is further cleaved into $\mathrm{P} 1, \mathrm{P} 2$, and $\mathrm{P} 3$ regions by viral proteases. The $2 \mathrm{~A}$ protease $\left(2 \mathrm{~A}^{\mathrm{pro}}\right)$ of poliovirus can cleave the $\mathrm{P} 1$ capsid protein from the polyprotein. In contrast, the $3 \mathrm{CD}$ protease cleaved the $\mathrm{P} 1, \mathrm{P} 2$, and $\mathrm{P} 3$ precursors [18]. The mature structural proteins can be used in virus assembly, and non-structural proteins for replication, apoptosis induction, innate immunity repression and in the shutting down of host cell translation (reviewed in [19]). The P1 region encodes the capsid proteins VP1 to VP4. The VP1, VP2, VP3, and VP4 proteins form a symmetrical icosahedral structure. VP1, VP2, and VP3 are exposed on the external surface of viral capsid, whereas VP1 is the highest exposed protein among the capsids [20-22]. VP4, however, is the smallest of the P1 proteins and arranged within the icosahedral lattice. The structural protein VP1 contains the primary binding residues to two identified EV-A71 receptors, P-selectin glycoprotein ligand-1 (PSGL-1) and scavenger receptor B2 (SCARB2) [23, 24]. Tyrosine sulfation in the N-terminal region of PSGL-1 facilitates EV-A71 viral entry and replication in leukocytes, thus affecting viral replication [25]. PSGL-1 alone was found to be insufficient in enhancing EV-A71 infection in mice [26], while SCARB2

(C) The Author(s). 2019 Open Access This article is distributed under the terms of the Creative Commons Attribution 4.0 International License (http://creativecommons.org/licenses/by/4.0/), which permits unrestricted use, distribution, and 
was found to be sufficient in causing neurological diseases in mice due to its roles in viral attachment, internalization, and uncoating [27]. In addition, some of the residues such as VP1-98, -145, and-164 [28], are antigenic sites for antibody recognition. The remaining P2 and $\mathrm{P} 3$ regions contain the non-structural proteins $2 \mathrm{~A}$ to $2 \mathrm{C}$ and $3 \mathrm{~A}$ to $3 \mathrm{D}$, respectively. $3 \mathrm{C}^{\text {pro }}$ can inhibit retinoic acid-inducible gene I (RIG-I) -mediated interferon response [29]. Also, $3 \mathrm{C}^{\text {pro }}$ assists in the interaction of $5^{\prime}$ UTR with RNA-dependent RNA polymerase (RdRp) $\left(3 \mathrm{D}^{\mathrm{pol}}\right)$ [29]. The RdRp lacks proofreading abilities, thus resulting in the high mutation rates of RNA viruses [30]. Since the amino acid changes might contribute to the alternation of protein properties, the substitutions within the viral genome may affect the viral protein interactions and replication. Here we focus on the review of the epidemiology, genetic evolution, antigenicity, and virulence determinants in EV-A71 viruses.

\section{Epidemiology of EV-A71}

The first EV-A71 isolate was identified in 1969 in the United States [31]. During the 1970s, several outbreaks of EV-A71 with HFMD were reported in the USA,
Australia, Japan, Hungary, Sweden, France, and Bulgaria [3, 31-37]. In the 1980s, outbreaks occurred in Asia, Brazil, Netherlands, and USA, but the viral activity reduced after these outbreaks [4, 38-42]. Starting from 1997, a large wave of EV-A71 activity appeared, causing HFMD around the Asia-Pacific region (Table 1). The first large HFMD and herpangina outbreak occurred in 1997 and further outbreaks appeared in 2000, 2003, and 2005 in Malaysia [6, 43]. In 1998, a large EV-A71 outbreak in Taiwan occurred, and increasing EV-A71 fatal cases were reported in 1999, 2000, 2001, 2004, 2005, 2008, and 2012 [44-47]. HFMD outbreaks were reported in Japan in the years 1984, 1987, 1990, 1997, 2000, and 2003, with the largest outbreak in 2003 [48]. Singapore had HFMD outbreaks in 2000, 2006, and 2008, with 2008 being the largest outbreak that Singapore had ever experienced $[49,50]$. China only had sporadic reported cases of EV-A71 before 2004. After 2004, EV-A71 began to spread to the middle and northern regions of China, leading to an outbreak of HFMD in 2008 and in 2012 [12, 51, 52]. Large outbreaks of HFMD caused by EVA71 were also reported in other countries such as Perth, Australia in 1999 [53], Vietnam in 2005, 2010-2011,

Table 1 EV-A71 genotype changes in endemic countries from 1997 to 2018

\begin{tabular}{|c|c|c|c|c|c|c|c|c|c|c|c|c|c|}
\hline & Australia & Austria & China & Japan & Korea & Malaysia & Netherlands & Norway & Singapore & Taiwan & UK & Thailand & Vietnam \\
\hline 1997 & B3 & & $C 2$ & $\mathrm{~B} 3, \mathrm{~B} 4, \mathrm{C} 2$ & & B3 $, B 4, C 1, C 2$ & $\mathrm{C} 1, \mathrm{C} 2$ & & $\mathrm{~B} 3, \mathrm{~B} 4, \mathrm{C} 1$ & & & & \\
\hline 1998 & $B 3, C 2$ & & C4 & $\mathrm{C} 2$ & & $\mathrm{~B} 4, \mathrm{C} 1$ & & & $\mathrm{~B} 3, \mathrm{C} 1$ & $\mathrm{~B} 3, \mathrm{~B} 4, \mathbf{C 2}, \mathrm{C} 4$ & $\mathrm{C} 1$ & & \\
\hline 1999 & $\mathrm{B3}^{\mathrm{ab}}, \mathrm{C} 2$ & & C4 & $\mathrm{C} 2$ & & $\mathrm{~B} 4, \mathrm{C} 1$ & $C 2$ & & B3 & $B 4, C 2$ & $\mathrm{C} 1, \mathrm{C} 2$ & & \\
\hline 2000 & $\mathrm{~B} 4, \mathrm{C} 1$ & & C4 & $\underline{\mathrm{B}}, \mathrm{C}, \mathrm{C}$ & C3 & B4,, C1 & $C 2$ & & $\underline{\mathbf{B} 4}, \mathrm{~B} 5, \mathrm{C1}$ & $\underline{\mathrm{B}}$ & $\mathrm{C} 1$ & & \\
\hline 2001 & $\mathrm{~B} 4, \mathrm{C} 1$ & C1 & C4 & $\mathrm{C} 2$ & C3 & $\mathrm{B} 4, \mathrm{C} 1$ & C1 & & $\mathrm{B} 4, \mathrm{C} 1$ & $\underline{\mathrm{B}}, \mathrm{C} 4$ & $\mathrm{C} 1$ & & \\
\hline 2002 & $\mathrm{C} 1$ & $\mathrm{C} 1$ & $C 2, C 4$ & $\mathrm{~B} 4, \mathrm{C} 2, \mathrm{C} 4$ & C3 & $\mathrm{B} 4, \mathrm{C} 1$ & $\mathrm{C} 1, \mathrm{C} 2$ & $\mathrm{C} 1$ & $\mathrm{~B} 4, \mathrm{C} 1$ & $\mathrm{~B} 4, \mathrm{C} 4$ & $\mathrm{C} 1$ & & \\
\hline 2003 & $\mathrm{C} 1, \mathrm{C} 4$ & $\mathrm{C} 1, \mathrm{C} 4$ & $C 2, C 4$ & $\mathrm{~B} 4, \mathrm{B5}, \mathrm{C4}$ & $C 3, C 4$ & $\mathrm{~B} 4, \mathbf{B 5}, \mathrm{C} 1$ & & $\mathrm{C} 1$ & $\mathrm{~B} 4, \mathrm{~B} 5, \mathrm{C} 1$ & $\mathrm{~B} 4, \mathrm{~B} 5, \mathrm{C} 2$ & & & \\
\hline 2004 & C4 & C4 & $C 2, C 4$ & $\mathrm{C} 4$ & & $\mathrm{~B} 5, \mathrm{C} 1$ & $\mathrm{C} 1, \mathrm{C} 2$ & & B5 & $\mathrm{C} 2, \underline{\mathrm{C}} 4$ & $\mathrm{C} 1$ & & \\
\hline 2005 & & & $C 2, C 4$ & C4 & C3 & $\mathrm{B} 5, \mathrm{C} 1$ & $\mathrm{C} 1, \mathrm{C} 2$ & & B5 & $\mathrm{C} 2, \underline{\mathbf{C 4}}, \mathrm{C5}$ & & & $\mathrm{C} 1, \mathrm{C} 4, \underline{\mathrm{C}} 5$ \\
\hline 2006 & & & $C 2, C 4$ & $\mathrm{C} 4$ & & B5 & & & B5 & $\mathrm{B} 5, \mathrm{C} 2, \mathrm{C} 4$ & $\mathrm{C} 1, \mathrm{C} 2$ & & \\
\hline 2007 & & & $C 2, C 4$ & $C 2, C 4$ & C4 & B5 & $\mathrm{C} 1, \underline{\mathrm{C} 2}$ & & B5 & $\mathrm{B} 5, \mathrm{C} 5$ & & & \\
\hline 2008 & & & $\mathrm{~A}, \mathrm{C} 2, \underline{\mathrm{C} 4}$ & $\mathrm{C} 2$ & C4 & B5 & $C 2$ & & $\underline{\mathrm{B}}, \mathrm{C} 2$ & B5 $, C 4, C 5$ & & $\mathrm{~B} 5, \mathrm{C1}, \mathrm{C} 2, \underline{\mathrm{C} 4}$ & \\
\hline 2009 & $C 2, C 4$ & & $C 2, C 4$ & $\mathrm{C} 2$ & $\mathrm{C} 2, \mathrm{C} 4$ & $\mathrm{~B} 5, \mathrm{C} 1$ & & & $\mathrm{~B} 4, \mathrm{~B} 5, \mathrm{C} 1$ & $\mathrm{~B} 5, \mathrm{C} 1$ & & $\mathrm{C} 1, \underline{\mathrm{C} 4}$ & \\
\hline 2010 & B3, C2 & & $C 2, C 4$ & $\mathrm{C} 2$ & C4 & B5 & & & & C4 & & B5 & C5 \\
\hline 2011 & & & C4 & & C4 & $\underline{\mathrm{B} 5}$ & & & & $\mathrm{~B} 5, \mathrm{C} 4$ & & B5 & $C 4, C 5$ \\
\hline 2012 & & & $\mathrm{C} 4$ & B5 & & B5 & & & & B5 & & $\underline{B 5}, \mathrm{C} 4$ & $\mathrm{~B} 5, \mathrm{C} 4, \mathrm{C} 5$ \\
\hline 2013 & & & C4 & B5 & & & & & & & & B5 & $C 4, C 5$ \\
\hline 2014 & & & C4 & & & & & & & & & & $\mathrm{B} 5, \mathrm{C} 4, \mathrm{C} 5$ \\
\hline \multicolumn{14}{|l|}{2015} \\
\hline 2016 & & & & C4 & & & & & & & & & C4 \\
\hline 2017 & & & & B5 & & & & & & & & B5 & \\
\hline 2018 & & & & B5 & & & & & & & & & \\
\hline
\end{tabular}

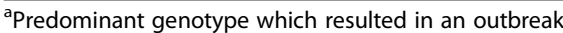

${ }^{b}$ Predominant genotypes were bold and underlined 
2012-2013, and 2016 [54, 55], Thailand in 2008-2009, 2011, and 2017 [14, 56, 57], and the Netherlands in 2007 [40]. These data suggest that the virus continued to circulate in the Asia-Pacific region, and had gradually spread to other countries.

\section{Genetic evolution}

Due to the error-prone RdRp, RNA viruses generate $10^{-}$ ${ }^{4}$ to $10^{-6}$ mutations per nucleotide [58], which leads to high mutation rates and increased genetic diversity [59]. Genetic evolution of EV-A71 can be clustered into three main genotypes $A, B$ and $C$, whereas genotypes $B$ and $C$ include five sub-genotypes, $\mathrm{B} 1-\mathrm{B} 5$ and $\mathrm{C} 1-\mathrm{C} 5$, respectively [60]. EV-A71 has been documented in several studies and observed inter- and intra-genotype shifts in the evolution around Asian-Pacific countries (Table 1). The shifts had also co-occurred with EV-A71 outbreaks.

Analyzing the genotypic changes according to the recent evolutionary studies reports, inter-genotype shifts appeared in Taiwan and Japan. The predominant strain of the 1998 outbreak in Taiwan was EV-A71 genotype C2 with $90 \%$ having recombination with coxsackievirus A8 (CV-A8) and the remaining 10\% were genotype B4 isolates $[45,61]$. The genotype B4 isolates from the 1998 outbreak had similar sequences to those of the 2000 outbreak. In the 2000 and 2001 outbreak in Taiwan, the predominant strain was genotype B4, thus showing an inter-genotype shift from $\mathrm{C} 2$ to $\mathrm{B} 4[8,62]$. The predominant genotype in 2004 and 2008 outbreaks changed from $\mathrm{B} 4$ to $\mathrm{C} 4$ and from $\mathrm{C} 4$ to $\mathrm{B} 5$, respectively. The same order of genotype shifts was observed in Japan with genotypes C2, B4, C4, and B5 (Table 1) [63, 64]. Contrary to inter-genotypic evolution, intra-genotypic evolution occurred in China. EV-A71 genotype C4, which was circulating in China, had shown the continuous evolution of the virus through non-outbreak years (2004-2007) to the outbreak years (2008-2012) [65]. In China, genotype $\mathrm{C} 4$ had persisted through time, showing annual increase in the accumulation of non-structural protein substitutions. Continuous accumulation of amino acid substitution within the same genotype $\mathrm{C} 4$ through non-outbreak to the outbreak period might explain why the same genotype activity dramatically increased after 2008 in China. Similar accumulation of substitutions especially in non-structural protein region has been reported among the genotype B5 in Taiwan. Genotype B5 had also been found to accumulate evolutionary amino acid substitutions in non-structural proteins, thus causing a re-emergent outbreak in Taiwan in 2012 in the following of the same genotype outbreak in 2008 (Fig. 1) [66].

Recombination of EV-A71 viruses is another common phenomenon. In poliovirus, high nucleotide sequence identities within a region, mainly seen in P2 and P3, of parental strains are in favor of homologous recombination via a 'copy-choice' mechanism, resulting in a possible combination that may favor survival during the natural selection process $[67,68]$. According to a study done by Woodman et. al., recombination was found to be a replicative process that is RdRp-mediated [69]. Both intra- and inter-typic recombination can be found in EV-A71 viruses. Complete EV-A71 genomes were sequenced and phylogenetically analyzed via swapping through the regions of the whole genome in order to analyze recombination events [70]. Recombination events were documented in countries such as Japan,

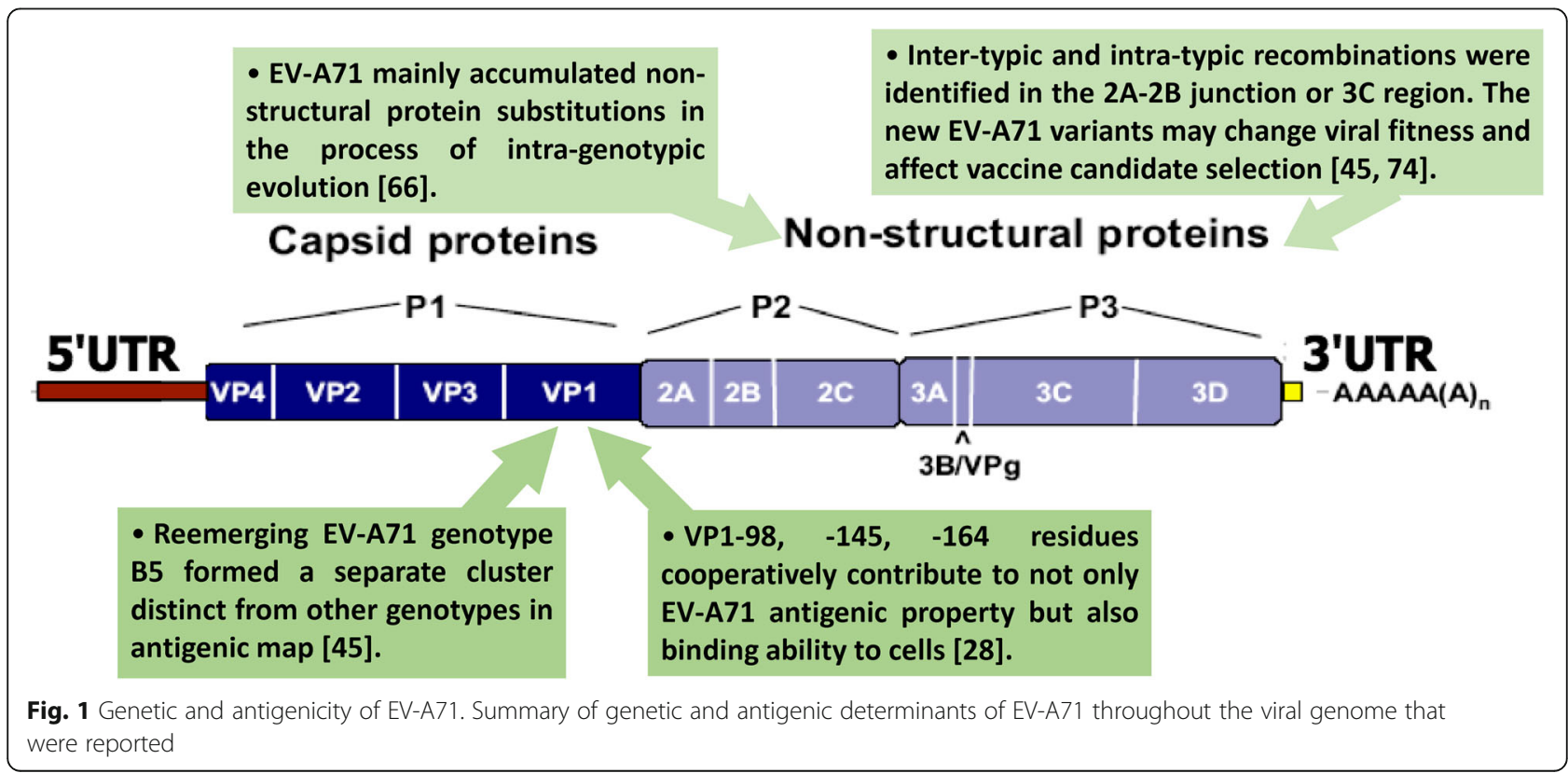


Malaysia, Singapore, and China [7, 45, 71-75]. Intertypic recombination was observed in 1997 isolates from an outbreak in Malaysia. Chan and AbuBakar had demonstrated that recombinations involving EV-A71 with CV-A16 [72], and EV-A71 genotype C4 isolates with genotype $\mathrm{C} 2$ and CV-A16/G10-like viruses were evident [71]. Inter-typic recombination was also seen in EV-A71 genotype C2 which was the major genotype in the 1998 outbreak in Taiwan and Japan [7, 45, 71]. During the EV-A71 genotype C2 outbreak in 1998, using bootscan analysis the virus sequence showed recombination between EV-A71 genotype C2 and coxsackievirus A8 [45, 76]. From the 2000-2001 outbreak, the predominant EV-A71 genotype was B4, however, recombination analysis by Huang et. al. showed that the sequence resulted in a recombination of genotypes B3 and B2 [45]. For the outbreak in 2004-2005, the predominant $C 4$ showed recombination between genotypes $\mathrm{C}$ and $\mathrm{B}$ [76]. Within these three outbreaks, both intra- and inter-genic recombination can be seen. Inter- and intra-typic recombinations were observed in China in a 2008 outbreak caused by both EV-A71 and coxsackievirus A16 (CVA16) [74]. Yip et. al. (2010) had observed recombination events at the 2A-2B junction in EV-A71 genotypes B with genotype $\mathrm{C}$, and EV-A71 genotype $\mathrm{B}$ with CV-A16 strain G-10 in the $3 \mathrm{C}$ region of EV-A71 viruses, while $\mathrm{CV}-\mathrm{A} 16$ strains were found to possess recombination at the $2 \mathrm{~A}-2 \mathrm{~B}$ junction between $\mathrm{CV}-\mathrm{A} 16$ strain $\mathrm{G}-10$ and EV-A71 genotype A [74]. Recombination of enteroviruses were also found in Central China in 2011-2012, where co-circulation of CV-A16 and EV-A71 genotype C4 was observed [77]. Woodman et. al. (2019) had developed a cell-based assay in order to observe recombination events of EV-A71 and found that recombination events were highest in $\mathrm{C} 2$ genotype followed by $\mathrm{C} 4$ then B5 [69]. Chen et. al. (2010) had previously reported on recombination breakpoints and recombination frequencies of EV-A71. Recombination breakpoint locations may vary depending on the strain and country, however, the $3 \mathrm{D}^{\mathrm{pol}}$ coding region shown to have the highest frequency at which recombination occurs as a unit [75].

\section{Virulence determinants of EV-A71}

For the last two decades, increasingly more effort has been placed in understanding EV-A71. Several virus virulence determinants have been identified for EV-A71. Since the generation of mouse-adapted EV-A71 [78], an amino acid change in VP1 position 145 was identified for the adapted virulence. The change was identified as glycine (G) changing to glutamic acid (E) $[79,80]$. Huang et. al. (2012) had also found that $\mathrm{VP} 1^{\mathrm{Q} 145 \mathrm{E}}$ enhances binding of EV-A71 to mouse neuroblastoma (Table 2) [86]. In a non-human primate model, VP1 ${ }^{145 \mathrm{E}}$ is responsible for the development of viremia and neuropathogenesis [90]. Huang et. al. (2012) observed that, in cooperation with $\mathrm{VP} 1^{\mathrm{Q} 145 \mathrm{E}}$, an amino acid change in VP2 at position 149 from lysine (K) to methionine $(\mathrm{M})\left(\mathrm{VP} 2^{\mathrm{K} 149 \mathrm{M}}\right)$ is associated with the increase of RNA accumulation, viral cytotoxicity and uncoating in mice neuronal cells, and an increase in mouse lethality in vivo [86]. In contrast, Chang et. al. (2012) had observed that an amino acid change from glutamic acid (E) to glutamine $(\mathrm{Q})$ in $\mathrm{VP} 1$ position $145\left(\mathrm{VP} 1^{\mathrm{E} 145 \mathrm{Q}}\right.$ ) was found in more severe cases of EV-A71 infections [87]. In addition, a VP1 $1^{145 \mathrm{G} / \mathrm{Q}}$ mutation had been found to be associated with the virus' ability to bind to the receptor PSGL-1 while VP1 ${ }^{145 \mathrm{E}}$ was associated with the inability to bind to PSGL-1 [88]. In a study done by van der Sanden et. al., (2018) they had found infectivity of the human airway organoids were EV-A71 strain-dependent. Coincidentally, the well-known position VP1-145 was also found to be a key determinant of infectivity of human airways. Van der Sanden et. al. had identified $\mathrm{VP} 1^{145 \mathrm{Q}}$ as a key determinant of increased infectivity in human airway organoids. In addition, in the absence of $\mathrm{VP} 1^{145 \mathrm{Q}}$, viruses with relatively high replication rates were found to have both VP1 $1^{98 K}$ and VP1 $1^{104 \mathrm{D}}$ mutations in genotype $\mathrm{C} 5$ strains. Therefore, $\mathrm{VP} 1^{98 \mathrm{~K}}$ and $\mathrm{VP} 1^{104 \mathrm{D}}$ may be potential infectivity markers in specific viral strains [89]. More recently, Huang et. al. (2017) had demonstrated the evolution of EV-A71 virus within a single autopsy case from the 1998 EV-A71 outbreak in Taiwan. EV-A71 viruses were isolated from various tissues and analyzed, thus showing the evolution of the virus within the host, as well as tissue tropism. They had identified a dominant haplotype switch from VP1-31D to VP1-31G, with VP1-31G being dominant in the central nervous system (CNS), indicating possible contribution to $\mathrm{CNS}$ invasion of the virus. The $\mathrm{VP}^{\mathrm{D} 31 \mathrm{G}}$ mutation was also found to enhance EV-A71 entry into neuroblastoma, increase virus growth rate and fitness in human neuronal cells, and had a higher proportion in the virus population in fatal patients than in HFMD patients [83]. Similarly, Cordey et. al. (2012) had analyzed the EV-A71 genome from various tissues of an immunocompromised patient. They had found that the mutation $\mathrm{VP} 1^{\mathrm{L} 79 \mathrm{R}}$, located in the $\mathrm{BC}$ loop region, plays a critical role in cell tropism and affects the viral binding ability and fitness in neuronal cells in vitro [84]. In another recent study, VP1 $1^{107 \mathrm{~A}}$ was found to regulate the maturation of EV-A71. Zhang et. al. had discovered that $\mathrm{VP} 1^{107 \mathrm{~A}}$ allowed greater flexibility of the VP1 BC loop and regulated the efficient cleavage of VP0, influencing maturation and viral uncoating, thus increasing viral replication [85]. Zaini et. al. (2012) found that a $\mathrm{VP} 1^{\mathrm{K} 244 \mathrm{E}}$ mutation is critical in mouse adaptation and virulence [91]. Nishimura et. al. (2013) had also found that mutations at VP1-244 can abolish virus binding to 
Table 2 Reported virulence determinants

\begin{tabular}{|c|c|c|c|}
\hline Region & Position/Factor & Observations & Ref \\
\hline \multirow[t]{2}{*}{$\overline{5^{\prime} \text { UTR }}$} & $158 \mathrm{C}$ & - Increases EV-A71 translation and virulence in mice & [81] \\
\hline & $\begin{array}{l}272 G, 488 U, \\
700 A / U\end{array}$ & - Associates with higher prevalence in severe cases of EV-A71 & [82] \\
\hline \multirow[t]{14}{*}{ VP1 } & $31 \mathrm{G}$ & $\begin{array}{l}\text { - Enhances EV-A71 entry into neuroblastoma } \\
\text { - Increases viral growth and fitness in human neuronal cells } \\
\text { - May facilitate CNS infection in humans }\end{array}$ & [83] \\
\hline & $31 \mathrm{D}$ & $\begin{array}{l}\text { - Enhances replication, infectivity, and fitness in colorectal cells } \\
\text { • Increases virion stability }\end{array}$ & [83] \\
\hline & L79R & $\begin{array}{l}\text { - Confers advantage in viral binding ability and fitness in neuronal cells } \\
\text { - Potential determinant of host-adaptation and neurovirulence in humans }\end{array}$ & [84] \\
\hline & $107 \mathrm{~A}$ & $\begin{array}{l}\text { - Regulates EV-A71 maturation via the efficient cleavage of VPO precursor } \\
\text { - Increases viral uncoating efficiency }\end{array}$ & [85] \\
\hline & 145 & - Under positive selection & [45] \\
\hline & Q145E & $\begin{array}{l}\text { - Enhances binding of EV-A71 to mouse neuroblastoma } \\
\text { - Increases viral binding and RNA accumulation of EV-A71 } \\
\text { - Cooperates with VP2 }{ }^{1149 M} \text { to increase mouse lethality in vivo }\end{array}$ & [86] \\
\hline & E145Q & - Observed in more severe cases & [87] \\
\hline & G145E & - Associates with increase in virulence in mice & $\begin{array}{l}{[79]} \\
{[80]}\end{array}$ \\
\hline & $145 \mathrm{Q} / \mathrm{G}, 244 \mathrm{~K}$ & - Associates with virus binding ability to PSGL-1 & [88] \\
\hline & $145 \mathrm{G} / \mathrm{Q} / \mathrm{R}, 164 \mathrm{E}$ & - Associates with higher prevalence in severe cases of EV-A71 & [82] \\
\hline & $145 \mathrm{Q}$ & - Key determinant of increased infectivity in human airway organoids & [89] \\
\hline & $98 \mathrm{~K}, 104 \mathrm{D}$ & - Potential infectivity markers of human airway organoids & [89] \\
\hline & $145 \mathrm{E}, 98 \mathrm{KJE}$ & $\begin{array}{l}\text { - Responsible for the development of viremia and neuropathogenesis, and increases levels of cytokines in } \\
\text { Cynomolgus monkey model }\end{array}$ & [90] \\
\hline & K244E & - Associates with mouse adaptation and virulence & [91] \\
\hline VP2 & K149 M & $\begin{array}{l}\text { - Increases RNA accumulation, viral toxicity, virulence, and uncoating in mouse neuronal cells } \\
\text { - Cooperates with VP1 }{ }^{\mathrm{Q145E}} \text { to increase infectivity and mouse lethality of EV-A71, and increases cytotoxicity in } \\
\text { Neuro-2a cells }\end{array}$ & [86] \\
\hline $2 \mathrm{~A}$ & $68 \mathrm{~K}$ & - Associates with higher prevalence in severe cases of EV-A71 & [82] \\
\hline \multirow[t]{2}{*}{$3 C$} & Region & - Can hamper the host innate defense by selectively blocking type I IFN synthesis & [92] \\
\hline & N69D & $\begin{array}{l}\text { - Decreases viral replication and virulence in RD cells } \\
\text { - Regulates } 3 C^{\text {pro }} \text { enzyme activity in mammalian cells }\end{array}$ & [93] \\
\hline 3D & $1251 \mathrm{~T}$ & $\begin{array}{l}\text { - Contributes to a strong temperature sensitivity } \\
\text { - Decreases virulence in neonatal mice }\end{array}$ & [94] \\
\hline
\end{tabular}

PSGL-1, while mutations at VP1-242 can influence virus binding. They had also proposed that depending on the protein at VP1-145, by its influence to control the exposure of the side-chain VP1 $1^{244 \mathrm{~K}}, \mathrm{VP} 1-145$ can act as a switch which controls PSGL-1 binding [88].

The $5^{\prime} \mathrm{UTR}^{\mathrm{U} 158 \mathrm{C}}$ was found to be associated with translation and virulence in mice [81]. Other $5^{\prime}$ UTR positions such as guanine at $272(272 \mathrm{G})$, uracil at 448 (448 U), and adenine/uracil at $700(700 \mathrm{~A} / \mathrm{U})$ have been found to be associated with higher prevalence in severe cases of EV-A71 [82]. Li et. al. had also reported on other mutations that were associated with higher prevalence in severe cases of EV-A71: VP1 ${ }^{145 G / Q / R}, V^{164 E}$, and $2 A^{68 K}[82]$. Apart from the structural region of the viral genome, the nonstructural region had also been found to play a role in the virulence of EV-A71. Amino acid substitutions in this region had been found to increase viral fitness (Fig. 1) [66]. The $3 \mathrm{C}$ region has been reported to be able to interfere with the host innate defense by selectively inhibiting the synthesis of type I interferon (IFN), and in 3D polymerase, an I251T mutation resulted in decreased virulence of MP4 (a mouse adapted strain of EV-A71) and can change the temperature sensitivity of the virus [92, 94]. Arita et. al. (2005) had also reported that temperature-sensitive mutants that are located in the $5^{\prime}$ UTR, $3 \mathrm{D}^{\mathrm{pol}}$, and $3^{\prime}$ UTR can cause an attenuation in neurovirulence [95]. The 69th residue of $3 C^{\text {pro }}$ has also been found to influence replication and virulence of EV-A71. A 3C $\mathrm{N}^{\mathrm{N} 69 \mathrm{D}}$ mutation had shown to attenuate virulence by impacting the substrate-binding site and catalytic active site. This mutation had also diminished $3 C^{\text {pro }}$ activity and its ability to shutoff host cell metabolism, inhibition of host cellular transcription and host 
immune system [93]. With being under constant selection pressure in hosts, mutations often aid viruses in surviving the different environments within a host. This is often seen in quasispecies whereby the viral population works in cooperation to adapt to adverse growth condition [96].

\section{Antigenicity}

With the increase in mutations, a change in antigenicity can also occur in addition to viral virulence. The capsid proteins have long been a target in producing antibodies against EV-A71 for immune system recognition. VP1 capsid region has been found to possess many antigenic determinants and is considered to play an important role in characterizing antigenicity [97]. Neutralizing antibodies (NAbs) against EV-A71 have been suggested as one of the most important factors in limiting the severity of EV-A71 infections [98]. Yu et. al. (2000) had demonstrated that adult mice were resistant to multiple EVA71 challenges, thus producing neutralizing antibodies post-infection that play a role in limiting severity of EVA71 infection. These neutralizing antibodies showed a protective role against EV-A71 by administering hyperimmune serum (1:128) 1-day post-infection in a mouse model. The anti EV-A71 NAbs was found to be able to effectively protect neonatal mice when passively immunized and when delivered and fed by an immunized dam [98]. Cross-neutralization activity of EV-A71 were also observed among various genotypes using guinea pig and rabbit antisera [99, 100]. Mizuta et. al. observed that guinea pig antisera against genotypes $\mathrm{B} 2$ and $\mathrm{C} 1$ had higher neutralization titers against genotypes B2, B4, and B5 but lower titers against genotypes A, C1, C2, and C4. Similarly, van der Sanden et. al. had similar results with rabbit antisera against genotypes B2 with higher neutralizing titers against genotypes B1 and B2 but lower titers against genotypes $\mathrm{C} 1, \mathrm{C} 2$, and $\mathrm{A}$. However, rabbit sera against genotype $\mathrm{C} 1$ showed higher neutralization activity with EV-A71 genotypes A, B, and C [100]. Huang et. $a l$. had previously investigated the cross reactivity and antigenic property of human antiserum from EV-A71 infected patients from 1998 to 2008 against human pathogenic EV-A71. Using sero-microneutralization data, an antigenic map was constructed which showed the antigenic diversity of the different genotypes. Based on this map, they had found that genotype B1 and B4 viruses were clustered closely together, genotype $\mathrm{C} 2$ and $\mathrm{C} 4$ formed a separate cluster from genotype $\mathrm{B}$ that was more spread out. Genotype B5, however, had formed its own cluster within the map (Fig. 1) [45]. These data suggest the difference in antigenic properties and the antigenic diversity among the various genotypes of EV-A71. Recently, Huang et. al. (2015) had confirmed that the amino acid residues VP1-98, - 145, and - 164 worked in a cooperative manner as antigenic determinants for B4 and B5 strains (Fig. 1). By creating reverse-genetics EVA71 viruses containing mutations at VP1-98 K, VP1$145 \mathrm{Q}$, and VP1-164E, they had found that these mutants significantly decreased neutralizing titers by 4 -fold against the antisera of 3 of the 6 healthy individuals [28]. However, it was also noted that none of the single mutation alone was responsible for the antigenic changes, but rather all 3 mutations cooperatively influence the viral antigenic phenotype. With a combination of genotypic shifts, antigenic changes, as well as recombination events, EV-A71 may possess many traits that allow for the virus to continuously persist and escape herd immunity. These factors would thus aid in the event of another outbreak.

\section{Conclusions}

Genotype shifts, changes in antigenic properties, and recombination events have shown to contribute to the evolution of EV-A71. Although there only genotype C4 available EV-A71 vaccine from China to date, increasing knowledge of the virus will better aid in the development of a vaccine that is able to protect against the different genotypes. Therefore, continuous surveillance of EV-A71 is required in order to better understand its epidemiology and viral evolution.

\section{Abbreviations \\ 2A $\mathrm{A}^{\text {pro: }}$ 2A protease; $3 \mathrm{C}^{\text {pro }}: 3 \mathrm{C}$ protease; 3D $\mathrm{pol}^{\mathrm{pl}}$ :3D polymerase; AFP: Acute flaccid paralysis; CNS: Central nervous system; CV-A16: Coxsackievirus A16; CV-A8: Coxsackievirus A8; EV-A71: Enterovirus A71; HFMD: Hand-foot-and- mouth disease; IFN: Interferon; IRES: Internal ribosome entry site; NAbs: Neutralizing antibodies; ORF: Open reading frame; PSGL-1: P-selectin glycoprotein ligand-1; RdRp: RNA-dependent RNA-polymerase; RIG-I: Retinoic acid-inducible gene I; RNA: Ribonucleic acid; SCARB2: Scavenger receptor B2; UTR: Untranslated Region}

\section{Acknowledgments \\ Not applicable}

Authors' contributions

SWH and JRW were involved in study concept and design. SWH and DC collected references and prepared the tables and figure. SWH, DC, and JRW wrote the article and gave final approval of submission.

\section{Funding}

This work was supported by the Ministry of Science and Technology, Taiwan (MOST) (grant numbers 107-2321-B-006-004-, 108-2321-B-006-012-, and 105-2320-B-006-032-MY3) and by the National Health Research Institutes, Taiwan (NHRI)

Availability of data and materials

Not applicable

Ethics approval and consent to participate Not applicable

Consent for publication

Not applicable

Competing interests

The authors declare that they have no competing interests. 


\section{Author details}

National Mosquito-Borne Diseases Control Research Center, National Health Research Institutes, Tainan, Taiwan. ${ }^{2}$ National Institute of Infectious Diseases and Vaccinology, National Health Research Institutes, Tainan, Taiwan. ${ }^{3}$ Department of Medical Laboratory Science and Biotechnology, College of Medicine, National Cheng Kung University, Tainan, Taiwan. ${ }^{4}$ Center of Infectious Disease and Signaling Research, National Cheng Kung University, One, University Road, Tainan 701, Taiwan. ${ }^{5}$ Department of Pathology, National Cheng Kung University Hospital, Tainan, Taiwan.

Received: 27 June 2019 Accepted: 1 October 2019 Published online: 21 October 2019

\section{References}

1. Lin TY, Chang LY, Hsia SH, Huang YC, Chiu CH, Hsueh C, et al. The 1998 enterovirus 71 outbreak in Taiwan: Pathogenesis and management. Clin Infect Dis. 2002;34(Supplement_2):S52-S7.

2. Ooi MH, Wong SC, Lewthwaite P, Cardosa MJ, Solomon T. Clinical features, diagnosis, and management of enterovirus 71. Lancet Neurol. 2010;9(11):1097-105.

3. Hagiwara A, Tagaya I, Yoneyama T. Epidemic of hand, foot and mouth disease associated with enterovirus 71 infection. Intervirology. 1978;9(1):60-3.

4. Samuda GM, Chang WK, Yeung CY, Tang PS. Monoplegia caused by enterovirus 71: an outbreak in Hong Kong. Pediatr Infect Dis J. 1987;6(2):206-8.

5. AbuBakar S, Chee HY, Al-Kobaisi MF, Xiaoshan J, Bing Chua K, Kit LS. Identification of enterovirus 71 isolates from an outbreak of hand, foot and mouth disease (HFMD) with fatal cases of encephalomyelitis in Malaysia. Virus Res. 1999;61(1):1-9.

6. Chua KB, Chua BH, Lee CS, Chem YK, Norizah I, Kiyu A, et al. Genetic diversity of enterovirus 71 isolated from cases of hand, foot and mouth disease in the 1997, 2000 and 2005 outbreaks, Peninsular Malaysia. Malaysian J Pathol. 2008;29(2):69-78.

7. Shimizu H, Utama A, Yoshii K, Yoshida H, Yoneyama T, Sinniah M, et al. Enterovirus 71 from fatal and nonfatal cases of hand, foot and mouth disease epidemics in Malaysia, Japan and Taiwan in 1997-1998. Jpn J Infect Dis. 1999:52(1):12-5.

8. Wang JR, Tsai HP, Chen PF, Lai YJ, Yan JJ, Kiang D, et al. An outbreak of enterovirus 71 infection in Taiwan, 1998. II. Laboratory diagnosis and genetic analysis. J Clin Virol. 2000;17(2):91-9.

9. Yip CCY, Lau SKP, Woo PCY, Yuen KY. Human enterovirus 71 epidemics: what's next? Emerg Health Threats J. 2013;6:19780.

10. Ooi MH, Wong SC, Podin Y, Akin W, del Sel S, Mohan A, et al. Human enterovirus 71 disease in Sarawak, Malaysia: A prospective clinical, virological, and molecular epidemiological study. Clin Infect Dis. 2007;44(5):646-56.

11. Ryu WS, Kang B, Hong J, Hwang S, Kim A, Kim J, et al. Enterovirus 71 infection with central nervous system involvement, South Korea. Emerg Infect Dis. 2010;16(11):1764-6.

12. Zhang Y, Zhu Z, Yang W, Ren J, Tan X, Wang Y, et al. An emerging recombinant human enterovirus 71 responsible for the 2008 outbreak of hand foot and mouth disease in Fuyang City of China. Virol J. 2010;7:94.

13. Sun LM, Zheng HY, Zheng HZ, Guo X, He JF, Guan DW, et al. An enterovirus 71 epidemic in Guangdong Province of China, 2008: epidemiological, clinical, and virogenic manifestations. Jpn J Infect Dis. 2011:64(1):13-8

14. Linsuwanon P, Puenpa J, Huang SW, Wang YF, Mauleekoonphairoj J, Wang $J R$, et al. Epidemiology and seroepidemiology of human enterovirus 71 among Thai populations. J Biomed Sci. 2014;21(1):16.

15. Brown BA, Pallansch MA. Complete nucleotide sequence of enterovirus 71 is distinct from poliovirus. Virus Res. 1995;39(2):195-205.

16. Lin JY, Li ML, Shih SR. Far upstream element binding protein 2 interacts with enterovirus 71 internal ribosomal entry site and negatively regulates viral translation. Nucleic Acids Res. 2009;37(1):47-59.

17. Thompson SR, Sarnow P. Enterovirus 71 contains a type I IRES element that functions when eukaryotic initiation factor elF4G is cleaved. Virology. 2003; 315(1):259-66

18. Nicklin MJ, Kräusslich HG, Toyoda H, Dunn JJ, Wimmer E. Poliovirus polypeptide precursors: expression in vitro and processing by exogenous 3C and 2A proteinases. Proc Natl Acad Sci U S A. 1987:84(12):4002-6.

19. Yuan J, Shen L, Wu J, Zou X, Gu J, Chen J, et al. Enterovirus A71 proteins: structure and function. Front Microbiol. 2018;9:286

20. Ma HC, Liu Y, Wang C, Strauss M, Rehage N, Chen YH, et al. An interaction between glutathione and the capsid is required for the morphogenesis of C-cluster enteroviruses. PLoS Pathogens. 2014;10(4):e1004052-e.
21. Hogle J, Chow M, Filman D. Three-dimensional structure of poliovirus at 2.9 A resolution. Science. 1985:229(4720):1358-65.

22. Toyoda H, Nicklin MJH, Murray MG, Anderson CW, Dunn JJ, Studier FW, et al. A second virus-encoded proteinase involved in proteolytic processing of poliovirus polyprotein. Cell. 1986;45(5):761-70.

23. Nishimura $Y$, Shimojima M, Tano $Y$, Miyamura T, Wakita T, Shimizu $H$. Human P-selectin glycoprotein ligand-1 is a functional receptor for enterovirus 71. Nat Med. 2009;15:794.

24. Yamayoshi S, Yamashita Y, Li J, Hanagata N, Minowa T, Takemura T, et al. Scavenger receptor B2 is a cellular receptor for enterovirus 71. Nat Med. 2009;15:798.

25. Nishimura $Y$, Wakita $T$, Shimizu $H$. Tyrosine sulfation of the amino terminus of PSGL-1 is critical for enterovirus 71 infection. PLoS Pathogens. 2010;6(11): e1001174-e.

26. Liu J, Dong W, Quan X, Ma C, Qin C, Zhang L. Transgenic expression of human P-selectin glycoprotein ligand-1 is not sufficient for enterovirus 71 infection in mice. Arch Virol. 2011;157:539-43.

27. Yamayoshi S, Ohka S, Fujii K, Koike S. Functional comparison of SCARB2 and PSGL1 as receptors for enterovirus 71. J Virol. 2013;87(6):3335-47.

28. Huang SW, Tai CH, Fonville JM, Lin CH, Wang SM, Liu CC, et al. Mapping enterovirus A71 antigenic determinants from viral evolution. J Virol. 2015; 89(22):11500-6.

29. Lei $X$, Liu $X$, Ma $Y$, Sun $Z$, Yang $Y$, Jin Q, et al. The 3 C protein of enterovirus 71 inhibits retinoid acid-inducible gene I-mediated interferon regulatory factor 3 activation and type I interferon responses. J Virol. 2010;84(16):8051-61.

30. Holland J, Spindler K, Horodyski F, Grabau E, Nichol S, VandePol S. Rapid evolution of RNA genomes. Science. 1982;215(4540):1577.

31. Schmidt NJ, Lennette $\mathrm{EH}, \mathrm{Ho} H \mathrm{H}$. An apparently new enterovirus isolated from patients with disease of the central nervous system. J Infect Dis. 1974; 129(3):304-9.

32. Kennett ML, Birch CJ, Lewis FA, Yung AP, Locarnini SA, Gust ID. Enterovirus type 71 infection in Melbourne. Bull World Health Organ. 1974:51(6):609-15.

33. Hagiwara A, Tagaya I, Komatsu T. Seroepidemiology of enterovirus 71 among healthy children near Tokyo. Microbiol Immunol. 1979;23(2):121-4.

34. Chumakov KM, Lavrova IK, Martianova LI, Korolev MB, Bashkirtsev VN, Voroshilova MK. Investigation of physicochemical properties of Bulgarian strain 258 of enterovirus type 71. Brief Report; 1979.

35. Tagaya I, Takayama R, Hagiwara A. A large-scale epidemic of hand, foot and mouth disease associated with enterovirus 71 infection in Japan in 1978. Jpn J Med Sci Biol. 1981;34(3):191-6.

36. Nagy G, Takátsy S, Kukán E, Mihály I, Dömök I. Virological diagnosis of enterovirus type 71 infections: experiences gained during an epidemic of acute CNS disease in Hungary in 1978. Arch Virol. 1982;71:217. https://doi. org/10.1007/BF01314873.

37. Chumakov M, Voroshilova M, Shindarov L, Lavrova I, Gracheva L, Koroleva G, et al. Enterovirus 71 isolated from cases of epidemic poliomyelitis-like disease in Bulgaria. Arch Virol. 1979;60(3):329-40

38. Gilbert GL, Dickson KE, Waters MJ, Kennett ML, Land SA, Sneddon M. Outbreak of enterovirus 71 infection in Victoria, Australia, with a high incidence of neurologic involvement. Pediatr Infect Dis J. 1988;7(7):484-7.

39. Hayward JC, Gillespie SM, Kaplan KM, Packer R, Pallansch M, Plotkin S, et al. Outbreak of poliomyelitis-like paralysis associated with enterovirus 71. Pediatr Infect Dis J. 1989;8(9):611-5.

40. van der Sanden S, Koopmans M, Uslu G, van der Avoort H. Dutch working Group for Clinical V. epidemiology of enterovirus 71 in the Netherlands, 1963 to 2008. J Clin Microbiol. 2009:47(9):2826-33.

41. EEd S, AMB F, Schatzmayr HG, Cortes LC. Evidence of enterovirus 71 infections in Brazil. Mem Inst Oswaldo Cruz. 1990:85:131-2.

42. Takimoto S, Waldman EA, Moreira RC, Kok F, de Paula PF, Saes SG, et al. Enterovirus 71 infection and acute neurological disease among children in Brazil (1988-1990). Trans R Soc Trop Med Hyg. 1998;92(1):25-8.

43. Podin Y, Gias ELM, Ong F, Leong YW, Yee SF, Yusof MA, et al. Sentinel surveillance for human enterovirus 71 in Sarawak, Malaysia: lessons from the first 7 years. BMC Public Health. 2006;6:180.

44. Ho M, Chen ER, Hsu KH, Twu SJ, Chen KT, Tsai SF, et al. An epidemic of enterovirus 71 infection in Taiwan. N Engl J Med. 1999;341(13):929-35.

45. Huang SW, Hsu YW, Smith DJ, Kiang D, Tsai HP, Lin KH, et al. Reemergence of enterovirus 71 in 2008 in Taiwan: dynamics of genetic and antigenic evolution from 1998 to 2008. J Clin Microbiol. 2009:47(11):3653-62.

46. Lin KH, Hwang KP, Ke GM, Wang CF, Ke LY, Hsu YT, et al. Evolution of EV71 genogroup in Taiwan from 1998 to 2005: an emerging of subgenogroup C4 of EV71. J Med Virol. 2006;78(2):254-62. 
47. Lin TY, Twu SJ, Ho MS, Chang LY, Lee CY. Enterovirus 71 outbreaks, Taiwan: occurrence and recognition. Emerg Infect Dis. 2003;9(3):291-3.

48. Hosoya M, Kawasaki Y, Sato M, Honzumi K, Kato A, Hiroshima T, et al. Genetic diversity of enterovirus 71 associated with hand, foot and mouth disease epidemics in Japan from 1983 to 2003. Pediatr Infect Dis J. 2006;25(8):691-4.

49. Wu Y, Yeo A, Phoon MC, Tan EL, Poh CL, Quak SH, et al. The largest outbreak of hand; foot and mouth disease in Singapore in 2008: the role of enterovirus 71 and coxsackievirus A strains. Int J Infect Dis. 2010;14(12):e1076-e81.

50. Chong CY, Chan KP, Shah V, Ng W, Lau G, Teo TS, et al. Hand, foot and mouth disease in Singapore: a comparison of fatal and non-fatal cases. Acta Paediatr. 2003;92(10):1163-9.

51. Wang Y, Zou G, Xia A, Wang X, Cai J, Gao Q, et al. Enterovirus 71 infection in children with hand, foot, and mouth disease in Shanghai, China: epidemiology, clinical feature and diagnosis. Virol J. 2015;12:83.

52. Yang $F$, Ren L, Xiong Z, Li J, Xiao Y, Zhao R, et al. Enterovirus 71 outbreak in the People's Republic of China in 2008. J Clin Microbiol. 2009;47(7):2351-2.

53. McMinn P, Stratov I, Nagarajan L, Davis S. Neurological manifestations of enterovirus 71 infection in children during an outbreak of hand, foot, and mouth disease in Western Australia. Clin Infect Dis. 2001:32(2):236-42.

54. Van Tu P, Thao NTT, Perera D, Truong KH, Tien NTK, Thuong TC, et al. Epidemiologic and virologic investigation of hand, foot, and mouth disease, southern Vietnam, 2005. Emerg Infect Dis. 2007;13(11):1733-41.

55. Le TV, Nguyen Van TT, Nguyen Quan H, Pham DT. Molecular epidemiology analysis of enterovirus 71 strains isolated in Dak Lak, Vietnam, 2011-2016. J Med Virol. 2019;91(1):56-64.

56. Puenpa J, Auphimai C, Korkong S, Vongpunsawad S, Poovorawan Y Enterovirus A71 infection, Thailand, 2017. Emerg Infect Dis. 2018; 24(7):1386-7.

57. Puenpa J, Theamboonlers A, Korkong S, Linsuwanon P, Thongmee C, Chatproedprai S, et al. Molecular characterization and complete genome analysis of human enterovirus 71 and coxsackievirus A16 from children with hand, foot and mouth disease in Thailand during 2008-2011. Arch Virol. 2011;156:2007-13.

58. Sanjuán R, Nebot MR, Chirico N, Mansky LM, Belshaw R. Viral mutation rates. J Virol. 2010;84(19):9733-48.

59. Duffy $S$, Shackelton LA, Holmes EC. Rates of evolutionary change in viruses: patterns and determinants. Nat Rev Gen. 2008;9:267.

60. Brown BA, Oberste MS, Alexander JP Jr, Kennett ML, Pallansch MA Molecular epidemiology and evolution of enterovirus 71 strains isolated from 1970 to 1998. J Virol. 1999;73(12):9969-75.

61. Kung SH, Wang SF, Huang CW, Hsu CC, Liu HF, Yang JY. Genetic and antigenic analyses of enterovirus 71 isolates in Taiwan during 1998-2005. Clin Microbiol Infect. 2007;13(8):782-7.

62. Wang JR, Tuan YC, Tsai HP, Yan JJ, Liu CC, Su IJ. Change of major genotype of enterovirus 71 in outbreaks of hand-foot-and-mouth disease in Taiwan between 1998 and 2000. J Clin Microbiol. 2002;40(1):10-5.

63. Fujimoto T, Chikahira M, Yoshida S, Ebira H, Hasegawa A, Totsuka A, et al. Outbreak of central nervous system disease associated with hand, foot, and mouth disease in Japan during the summer of 2000: detection and molecular epidemiology of enterovirus 71. Microbiol Immunol. 2002;46(9):621-7.

64. Mizuta K, Abiko C, Murata T, Matsuzaki Y, Itagaki T, Sanjoh K, et al. Frequent importation of enterovirus 71 from surrounding countries into the local community of Yamagata, Japan, between 1998 and 2003. J Clin Microbiol. 2005;43(12):6171.

65. Zhang Y, Tan X, Cui A, Mao N, Xu S, Zhu Z, et al. Complete genome analysis of the C4 subgenotype strains of enterovirus 71: predominant recombination C 4 viruses persistently circulating in China for 14 years. PloS One. 2013;8(2):e56341-e.

66. Huang SW, Cheng HL, Hsieh HY, Chang CL, Tsai HP, Kuo PH, et al. Mutations in the non-structural protein region contribute to intra-genotypic evolution of enterovirus 71. J Biomed Sci. 2014;21(1):33.

67. Jarvis TC, Kirkegaard K. Poliovirus RNA recombination: mechanistic studies in the absence of selection. EMBO J. 1992;11(8):3135-45.

68. Kirkegaard K, Baltimore D. The mechanism of RNA recombination in poliovirus. Cell. 1986;47(3):433-43.

69. Woodman A, Lee K-M, Janissen R, Gong YN, Dekker NH, Shih SR, et al. Predicting intraserotypic recombination in enterovirus 71 . Virol. 2019;93(4):e02057-18.
70. Santti J, Hyypiä T, Kinnunen L, Salminen M. Evidence of recombination among enteroviruses. J Virol. 1999;73(10):8741-9.

71. Chan YF, AbuBakar S. Phylogenetic evidence for inter-typic recombination in the emergence of human enterovirus 71 subgenotypes. BMC Microbiol. 2006;6:74.

72. Chan YF, AbuBaker S. Recombinant human enterovirus 71 in hand, foot and mouth disease patients. Emerg Infect Dis. 2004;10(8):1468-70.

73. Huang SC, Hsu YW, Wang HC, Huang SW, Kiang D, Tsai HP, et al. Appearance of intratypic recombination of enterovirus 71 in Taiwan from 2002 to 2005. Virus Res. 2008;131(2):250-9.

74. Yip CCY, Lau SKP, Zhou B, Zhang MX, Tsoi HW, Chan KH, et al. Emergence of enterovirus 71 "double-recombinant" strains belonging to a novel genotype D originating from southern China: first evidence for combination of intratypic and intertypic recombination events in EV71. Arch Virol. 2010:155(9):1413-24.

75. Chen X, Zhang Q, Li J, Cao W, Zhang JX, Zhang L, et al. Analysis of recombination and natural selection in human enterovirus 71 . Virology. 2010;398(2):251-61.

76. Huang SW, Kiang D, Smith DJ, Wang JR. Evolution of re-emergent virus and its impact on enterovirus 71 epidemics. Exp Biol Med. 2011;236(8):899-908.

77. Liu W, Wu S, Xiong Y, Li T, Wen Z, Yan M, et al. Co-circulation and genomic recombination of coxsackievirus A16 and enterovirus 71 during a large outbreak of hand, foot, and mouth disease in Central China. PloS One. 2014; 9(4):e96051-e.

78. Wang YF, Chou CT, Lei HY, Liu CC, Wang SM, Yan JJ, et al. A mouseadapted enterovirus 71 strain causes neurological disease in mice after oral infection. J Virol. 2004:78(15):7916-24.

79. Arita M, Ami Y, Wakita T, Shimizu H. Cooperative effect of the attenuation determinants derived from poliovirus Sabin 1 strain is essential for attenuation of enterovirus 71 in the NOD/SCID mouse infection model. J Virol. 2008;82(4):1787-97.

80. Chua BH, Phuektes P, Sanders SA, Nicholls PK, McMinn PC. The molecular basis of mouse adaptation by human enterovirus 71. J Gen Virol. 2008;89(7):1622-32.

81. Yeh MT, Wang SW, Yu CK, Lin KH, Lei HY, Su IJ, et al. A single nucleotide in stem loop II of 5'-untranslated region contributes to virulence of enterovirus 71 in mice. PloS One. 2011;6(11):e27082-e.

82. Li R, Zou Q, Chen L, Zhang H, Wang Y. Molecular analysis of virulent determinants of enterovirus 71. PloS One. 2011;6(10):e26237-e.

83. Huang SW, Huang YH, Tsai HP, Kuo PH, Wang SM, Liu CC, et al. A selective bottleneck shapes the evolutionary mutant spectra of enterovirus A71 during viral dissemination in humans. J Virol. 2017;91(23):e01062-17.

84. Cordey S, Petty TJ, Schibler M, Martinez Y, Gerlach D, van Belle S, et al. Identification of site-specific adaptations conferring increased neural cell tropism during human enterovirus 71 infection. PLoS Pathogens. 2012; 8(7):e1002826-e.

85. Zhang YX, Huang YM, Li QJ, Li XY, Zhou YD, Guo F, et al. A highly conserved amino acid in VP1 regulates maturation of enterovirus 71. PLoS Pathogens. 2017;13(9):e1006625-e.

86. Huang SW, Wang YF, Yu CK, SU IJ, Wang JR. Mutations in VP2 and VP1 capsid proteins increase infectivity and mouse lethality of enterovirus 71 by virus binding and RNA accumulation enhancement. Virology. 2012:422(1):132-43.

87. Chang SC, Li WC, Chen GW, Tsao KC, Huang CG, Huang YC, et al. Genetic characterization of enterovirus 71 isolated from patients with severe disease by comparative analysis of complete genomes. J Med Virol. 2012;84(6):931-9.

88. Nishimura Y, Lee H, Hafenstein S, Kataoka C, Wakita T, Bergelson JM, et al. Enterovirus 71 binding to PSGL-1 on leukocytes: VP1-145 acts as a molecular switch to control receptor interaction. PLoS Pathogens. 2013;9(7):e1003511-e.

89. van der Sanden SMG, Sachs N, Koekkoek SM, Koen G, Pajkrt D, Clevers H, et al. Enterovirus 71 infection of human airway organoids reveals VP1-145 as a viral infectivity determinant. Emerg Microbes Infect. 2018;7(1):84.

90. Kataoka C, Suzuki T, Kotani O, Iwata-Yoshikawa N, Nagata N, Ami Y, et al. The role of VP1 amino acid residue 145 of enterovirus 71 in viral fitness and pathogenesis in a cynomolgus monkey model. PLoS Pathogens. 2015;11(7):e1005033-e.

91. Zaini Z, Phuektes P, McMinn P. Mouse adaptation of a sub-genogroup B5 strain of human enterovirus 71 is associated with a novel lysine to glutamic acid substitution at position 244 in protein VP1. Virus Res. 2012;167(1):86-96. 
92. Lee YP, Wang YF, Wang JR, Huang SW, Yu CK. Enterovirus 71 blocks selectively type I interferon production through the 3 C viral protein in mice. J Med Virol. 2012;84(11):1779-89.

93. Li B, Yue Y, Zhang Y, Yuan Z, Li P, Song N, et al. A novel enterovirus 71 (EV71) virulence determinant: the 69th residue of $3 \mathrm{C}$ protease modulates pathogenicity. Front Cell Infect Microbiol. 2017;7:26.

94. Kung YH, Huang SW, Kuo PH, Kiang D, Ho MS, Liu CC, et al. Introduction of a strong temperature-sensitive phenotype into enterovirus 71 by altering an amino acid of virus 3D polymerase. Virology. 2010;396(1):1-9.

95. Arita M, Shimizu H, Nagata N, Ami Y, Suzaki Y, Sata T, et al. Temperaturesensitive mutants of enterovirus 71 show attenuation in cynomolgus monkeys. J Gen Virol. 2005;86(5):1391-401.

96. Lauring AS, Andino R. Quasispecies theory and the behavior of RNA viruses. PLoS Pathogens. 2010;6(7):e1001005-e.

97. Shih SR, Li YS, Chiou CC, Suen PC, Lin TY, Chang LY, et al. Expression of capsid protein VP1 for use as antigen for the diagnosis of enterovirus 71 infection. J Med Virol. 2000;61(2):228-34.

98. Yu CK, Chen CC, Chen CL, Wang JR, Liu CC, Yan J-J, et al. Neutralizing antibody provided protection against enterovirus type 71 lethal challenge in neonatal mice. J Biomed Sci. 2000;7(6):523-8.

99. Mizuta K, Aoki Y, Suto A, Ootani K, Katsushima N, Itagaki T, et al. Crossantigenicity among EV71 strains from different genogroups isolated in Yamagata, Japan, between 1990 and 2007. Vaccine. 2009;27(24):3153-8.

100. van der Sanden S, van der Avoort H, Lemey P, Uslu G, Koopmans M. Evolutionary trajectory of the VP1 gene of human enterovirus 71 genogroup B and C viruses. J Gen Virol. 2010;91(8):1949-58.

\section{Publisher's Note}

Springer Nature remains neutral with regard to jurisdictional claims in published maps and institutional affiliations.

Ready to submit your research? Choose BMC and benefit from:

- fast, convenient online submission

- thorough peer review by experienced researchers in your field

- rapid publication on acceptance

- support for research data, including large and complex data types

- gold Open Access which fosters wider collaboration and increased citations

- maximum visibility for your research: over $100 \mathrm{M}$ website views per year

At $\mathrm{BMC}$, research is always in progress.

Learn more biomedcentral.com/submissions 